HISTORY, TEXT AND HERMENEUTICS:

\title{
A BLACK THEOLOGY APPRAISAL OF JUDGES 12:1-6 TRANSLATIONS INTO AFRICAN LANGUAGES
}

\author{
L Bookholane \\ Church History \& Missiology \\ University of South Africa
}

\begin{abstract}
The recent and recurring xenophobia/Afrophobia ${ }^{1}$ in the democratic South Africa contradicts the notion of God's preferential option for the poor and the Church's critical solidarity with the poor. The contradiction was exacerbated by the institutionalization of the notion of the Church's critical solidarity with the state. ${ }^{2}$ It is in particular a disgrace to the liberating and humanizing legacy of Black Theology in South Africa. This essay reflects on language particularly Bible translation in the incitement of prejudice, stigma, discrimination and violence amongst Black South Africans during the colonial apartheid dispensation ${ }^{3}$ and now towards the Black African Other ${ }^{4}$ in the democratic South Africa. In dialogue with the Afrikaans Bible translation it underscores the need to learn from the lessons of the Afrikaners who fought against colonialism and imperialism in order to avoid the pitfalls of becoming the domestic oppressors. Towards that end the essay engages in critical reflection on the Bible translation in African languages that they do not serve the indigenous process of resisting but reinforce continued colonial and imperial domination through tribalism and ethnicity. It concludes by submitting that Black Theology practitioners need to contest the power of Bible translation in African languages in order to liberate the Bible ideology of liberation of all people and nations from colonial and imperial ideologies which are now gullibly accepted as the Word of God.
\end{abstract}

Key Words: Bible Translation, Afrikaans and African Languages, Xenophobia/ Afrophobia, Contextualization, Black Theology

\section{Introduction}

Observations have been made about the proliferation of English and Afrikaans translations of the Bible. ${ }^{5}$ The mushrooming interpretations and translations of the biblical text in

Gathogo, JM \& Phiri, IA "Xenophobia/Afrophobia in Post-Apartheid (South) Africa: Strategies for Combat" Theologia Viatorum 33/2 2009:216-241.

2 Barney N Pityana and Charles Villa-Vicencio, (eds.), Being the Church in South Today. Papers delivered at the Consultation on South Africa in Regional and Global Context: Being the Church Today. Vanderbijlpark March 19-23, 1995. Johannesburg: South African Council of Churches, 1995.

3 Simons S Maimela, "Man in 'White' theology", Missionalia 9/2 August 1981:64-78. Simon S Maimela, "Man in 'White' Theology." Journal of Theology for Southern Africa 1981:27-42.

$4 \quad$ Reggie W Nel \& Karabo M Makofane, 2009 “Exploring the Notion of the 'African Other', from the Perspective of 'Oikos', towards Building Inclusivity: Reflections on the Response of URCSA in the Wake of the Recent Violent Attacks against Black African Nationals". Theologia Viatorum 33/2 2009:374-399.

5 John Lübbe, “A New Bible translation: 'The Syntactic Translation'?” Old Testament Essays 22:3, 2009:605617. 
general and Judges 12:1-6 in particular comply with the constitutional recognition of languages as long as they do not fan the flames of ethnocentricism. It is expected that the gains made during the phase of the struggle for liberation in South Africa, by enlisting the sanctioning role of the Bible would be built upon in the phase of the struggle for building a unified nation. Also, that restraint would be exercised by all and sundry against the use of language diversity to feed prejudice, stigma, discrimination and violence especially towards the Black African Other. However, the daily experiences of the majority of members of the South African society confirm the suspicion that the current rulers are never willing to learn from the lessons of their predecessors and that the end result is inevitably the same. An example in this regard is the erstwhile violent apartheid policy where Black people were divided and discriminated against in terms of amongst other things the languages they spoke. Ironically in the democratic South Africa the elite succumb to the temptation to use whatever means necessary including diversity of languages to divide and oppress their own people who fought side by side in the struggle for liberation but wish to enjoy the fruit of liberation alone. Unless vigilance is being exercised the danger of the constitutional recognition of African Languages ${ }^{6}$ being abused to reinforce the erstwhile oppressive hierarchies and structures of violence. ${ }^{7}$ We are called upon to enlist the language resources in their diversity to continue the legacy of the indigenous process of resistance against all forms of oppression and from whatever quarters.

A complementary observation that needs to be made about the mushrooming translations of the Bible into the former only two official ${ }^{8}$ languages is that the translation enterprise is still in the hands of the people who speak these languages in general and those who can afford the translation costs. This is not the case with the translation of the Bible into African languages ${ }^{9}$ which are still in the hands and under the control of the Bible Society of South Africa together with their translation agencies and translation consultants. The currently available interpretations and translations of the Bible in African Languages ${ }^{10}$ are without exception only from the copyright of the Bible Society of South Africa ${ }^{11}$. There are no other independent versions as in for example Afrikaans ${ }^{12}$ and English languages. As a result advocates and practitioners of Black Theology have to rely on the versions available from this benevolent organisation. The Black interpreters and translators who participate in the African Languages products are in the main practitioners of the respective individualised languages and in some case do not have any formal Hebrew and Greek languages as their Afrikaans and English counterparts, and also they do not have theological let alone Black theological training background. Furthermore, these practitioners who in the main provide consultancy services only take serious the dynamic interaction between social analysis and interpretation and translation only in so far as the process and product reinforce inherited erstwhile hierarchies, including between languages and the people who speak

6 Constitution of South Africa Act, 1996 (Act No.108 of 1996) Section 6 (1).

7 Hassim Shireen, Tawana Kupe and Eric Worby, (eds.), Go Home or die Here: Violence, Xenophobia and Reinvention of Difference in South Africa, (Johannesburg, South Africa: Wits University Press, 2008:16.

8 Madipoane Masenya, "What differences do African contexts make for English translations?" Old Testament Essays 14/2 2001:281-296.

9 Sepedi, Sesotho, Setswana, siSwati, Tshivenda, Xitsonga, isiNdebele, isiXhosa and isiZulu.

10 See how the African Languages are being referred to in the Constitution of South Africa Act, 1996 (Act No.108 of 1996) Section 6 (1).

11 See how 17 years after the dawn of constitutional democracy they continue to refer to the African Languages contrary to their reference in the Constitution.

12 See the supermarket list of Afrikaans versions consulted. 
them, rather than contribute towards challenging them. Furthermore, it would appear that in the African Languages no difference and differentiation is made between history, text and interpretation and translation hence the proclivity to succumb to the temptation to think that theirs is to reproduce in their contemporary situation a carbon copy of the ancient history oblivious of the fact that the text as it now stands is itself a veritable re/construction. What is worse is when you have the African Languages interpretation and translation serving the role of reinforcing erstwhile hierarchies of superiority and inferiority by reproducing the cultures and ideological struggles embodied in the Afrikaans and English translations and peddle them as the 'Word of God' for Black People.

What this means is that what the speakers of the African languages read about does not yet give voice to their aspirations, is not from their pen and does not express their worldview. The translations of the Bible into the African Languages are still those developed during the erstwhile apartheid. The role which the Bible and the African Languages served has not changed and still continues unabated. In this regard, it is important to find out what is the role that the translations of the Bible into the African Languages play in the polarization of the people who speak these languages into the ethnocentric ${ }^{13}$ and tribal fierce enemies:

Having been taught to presuppose the worst in human relations and dealings with one another, it should not surprise us that even so-called White Christians will easily and without reflection work to discourage contacts between Black ethnic groups, who for their good must be separated into safe and self-enclosed entities. ${ }^{14}$

and

Indeed, we have people who have concluded that Whites do not only have the 'swart gevaar' and 'race problem' in their hands but also South Africans collectively have innumerable dangers that each ethnic group poses for all the others. It becomes a risky business to marry and live among Zulus if one is a Sotho, etc. ${ }^{15}$

In order for us as the members of the South African society to be able to begin to deal with xenophobia and Afrophobia, we need to get the translation enterprise into the hands of the people who speak the African Languages the same way as the translation of the Bible into English and Afrikaans is in the hands of the speakers of these languages. It is only fair and equitable that the translation of the Bible into African Languages must be done by the speakers themselves of these languages. The speakers of the African Languages will also be the veritable interlocutors and dialogue partners as active participants of the receiving community of the biblical text in the translation process. In this way the prospects for translation in the process of contextualization will be enhanced.

Black Theology proponents and practitioners need to contest the translation enterprise as they have done with hermeneutics. They need to help loosen the grip of colonial apartheid on the African Languages and the translation of the Bible into these languages. Speakers of African Languages will be able to identify with the translation of the Bible into their languages because it will be their product. When they want affirmation they will no longer go to the English versions and mistake the affirmation of the readers' humanity as

13 Gathogo \& Phiri, "Xenophobia/Afrophobia in Post-Apartheid (South) Africa," 218. NA Botha, "If everything is contextualisation, nothing is contextualization: Historical, methodological and epistemological perspectives." Missionalia 38/2 August 2010:181-196.

14 Maimela, Missionalia, 69.

15 Maimela, Journal of Theology for Southern Africa, 33. 
referring to themselves. Black Theologians should no longer continue to defer the translation enterprise to the Bible Society of South African and their translation consultants, who may not share the role of translation in the contextualization ${ }^{16}$ of the Gospel amongst the indigenous people. In this way the message of the Bible will be accessible to all the Black people, and not just a few albeit now including the elite amongst the speakers of the African Languages. When the speakers of the African Languages ask the question "What does the Bible say about it?"17 or when they say "The Bible says"18 they will no longer refer to a translation product not of their own. It will be their translation of the Bible into their languages as they understand them and wish it to be. It will be a translation of the Bible into their languages that resonate with their worldview and idiom. ${ }^{19}$

In this article an attempt is made to put into practice what we are suggesting i.e. to take the translation of the Bible into the African Languages serious by looking at the problems inherent in the translation of Judges 12:1-6. Our premise is that this biblical text is not prescriptive, that is, how people ought to relate to one another on the basis of language and pronunciation but that it is prohibitive, that is, how not to relate to one another on the basis of language and pronunciation diversity. An appraisal of the interpretation and translation of Judges is made from a South African Black Theology perspective that is in terms of the prohibitive nature of the material of Judges 12:1-6 how deep we should go in terms of appropriating the prohibition in our contemporary situation, namely, not just towards nationals of other countries but also towards fellow South Africans. A conclusion wraps up the argument of this essay that in this material context Black Theology in South Africa has her work cut out to contest the power of Bible translation in African Languages in order to liberate the Bible message of liberation of all people and nations from ethnocentricism through language, colonial and imperial ideologies which are now gullibly accepted as the Word of God.

\section{A Black Theological Appraisal of Judges 12:1-6}

Our premise is that the translation enterprise is not a neutral exercise despite claims to the contrary. It is as much and no less a site of struggle as the hermeneutic activity. No one group or stakeholder may be entrusted with the task of doing it for the others, especially when the translation into their languages they would not entrust to anybody except themselves. Hence the translation of the Bible into African Languages must be contested if it were to enhance contextualization of the Gospel to the indigenous communities.

Judges 12:1-6 forms an integral narrative unit and that the narrative integrity should not be sacrificed by just focusing on one verse, namely part of verse 6 viz. שִשּב לְת These six verses deal with two crusts of tragedy, vss. 1-3 the fight against the sons of Ammon and vss. 4-6 the fight against the men of Ephraim. These two crusts of national and ethnic tragedies are held together by the personal tragedy that befell Jephthah with the sacrifice of his daughter, without which the two national tragedies are incomprehensible. We are now going to look at the six verses individually and how they fit together to form a

16 Botha, "If everything is contextualisation, nothing is contextualization," 184-190.

17 Johanna Stiebert, "Does the Hebrew Bible have anything to tell us about HIV/AIDS?" Missionalia 29/2 August 2001:174-185

18 Sarojini Nadar, “"The Bible Says!' Feminism, Hermeneutics and Neo-Pentecostal Challenges.” Journal of Theology for Southern Africa 134 July 2009:131-146.

19 William E Bivin, "Mothertongue Translations and Contextualization in Latin America." International Bulletin of Missionary Research 34/2 April 2010:72-76. 
narrative unit, something that is lacking in the various translations into the African Languages. What is also crucial is the narrative progression to the climax in verse 6 .

1

The African Languages translation are divided between the point of compass 'northward' and a place name as the evidence below indicates. The one group translate it as 'leboa' (Judges 12:1 Sepedi), 'bokone' (Judges 12:1 Setswana), 'Livhuya' (Judges 12:1 Tshivenda), 'mavalungweni' (Judges 12:1 Xitsonga), 'entla' (Judges 12:1 isiXhosa), 'ngasenyakatho' (Judges 12:1 isiZulu), 'noorden' (Judges 12:1 Dutch). The other group following the Afrikaans and English translation simply transliterate it: 'Safone' (Judges 12:1 Sesotho), 'kulaseSafoni' (Judges 12:1 siSwati), 'Safon' (Rigters 12:1 Afrikaans), 'Zaphon' (Judges 12:1 English). The majority of the African Languages however opt for 'northward'. It is only the Dutch that also opts for 'northward'. The Afrikaans and English translations opt for the place name.

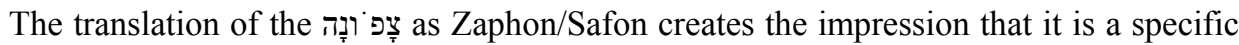
place name and confines Jephthah's military occupation to a specific place only whereas the rendering of it as a point of compass 'northward' is to a bigger territory which includes the specific place where the men of Ephraim met and confronted Jephthah.

The choice 'for' Safon as a place name or point of compass 'northward' is informed by clear ideological choices and not just simply because of the MSS that is being followed. In the case of the African Languages one may be forgiven for observing the influence of English and Afrikaans as in the case of Sesotho and siSwati. It would be interesting to see whether the choice for 'Safon' in all the translations consulted has something to do with the aversion for 'going northward' given the invasions carried out during the apartheid regime. The question is whether the aversion to interpret and translate as 'northward' is in some way to block out the memory of apartheid led invasion of the people 'northward' and projection of the fear to be befallen by the fate of the Ephraimites or whether the choice for the interpretation and translation of 'northward' make a connection with the struggles of the Black people against imperial, colonial and apartheid led invasions. Furthermore, whether the choices made for both interpretation and translation is consistently carried through the whole narrative, at least Judges 12:1-6. What is of more interest though would be whether the preference for 'going northward' as is borne in most of the African Languages, is a conscious ideological choice made. What is of paramount importance though is whether the preference made for either 'Safon' or 'northward' is regarded as a standalone or is carried through and informs the interpretation and translation of the whole narrative. The parallel references in Judges $2: 9 ; 7: 1 ; 21: 9$ indicate to the point of compass.

The other issue surfaced in this verse is the threat of the men of Ephraim to 'burn your house'. The question to ask at this point is whether the 'burn your house' is the first or an option at all to resolve conflict. It just does not make sense that the men of Ephraim threatened to " "burn' Jephthah's house" simply because he allegedly went to fight their common enemy alone and did not invite them to go with him.

2

The African Languages are divided between 'nation' and 'people'. 'setshaba' (Judges 12:2 Sepedi), 'setjhaba' (Judges 12:2 Sesotho), 'morafe' (Judges 12:2 Setswana), 'abantu' (Judges 12:2 siSwati), 'vhathu' (Judges 12:2 Tshivenda), 'abantu' (Judges 12:2 isiXhosa), 
'abantu' (Judges 12:2 isiZulu). The English translate as 'people' (Judges 12:2 English). The Afrikaans translation evolve from the cultural 'volk' (Rigters 12:1 Afrikaans), to the military 'manskappe' (Rigters 12:1 Afrikaans), 'soldate' (Rigters 12:1) in line with the unfolding of their history. This is missing in the African Languages translation, where the rendering does not seem to resonate with the individual and collective historical experiences of the people who speak these languages. Is this explained by the fact that the translation enterprise was not in their hands; also if the Bible Society of South Africa was also overseeing the Afrikaans translation, what would have been the cause of such preferential treatment on the histories of the receiving communities. ${ }^{20}$ Or is it a matter of in one translation there is focus on the receiving community and on the other it is on the text itself? ? $^{21}$

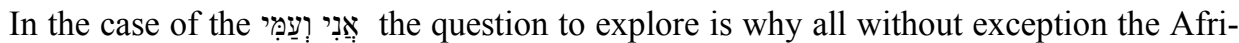
can Languages interpretations and translations render it with 'people' or 'nation' etc. in contrast to the Afrikaans who initially rendered it using cultural construct 'volk' and later onwards military construct 'soldate', 'manskappe'. This is so in case of the African Languages even when the context of the narrative and the choice of words on the one hand and on the other the contemporary situation within which the interpretation and translation enterprise is being undertaken points to the contrary. In short, what is the ideological rationale for one interpretation and translation to resonate with the evolving social context and the other to be so removed from it? When it appears that Afrikaans interpretations and translation provided religious sanction to the soldiers, one wonders who the African Languages interpretations and translations were providing sanction for, if not the soldiers of the liberation movement.

All the African Languages interpretation and translations demilitarize the combatants by

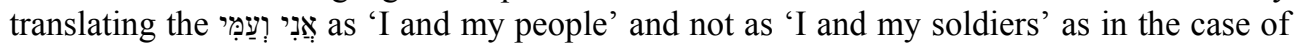
the Afrikaans translation at the time. By so doing the fight between the men of Ephraim and the Gileadites under Jephthah is turned into a perennial tribal feud where all members of these tribes where condemned to congenital strife. However, the fact of the matter is that this was just competition for hegemony between groups fighting for power and not necessarily defined in terms of their blood relation as it happened between the Gileadites and the sons of Ammon.

The Afrikaans interpretation and translation construct started from 'Ek en my volk' and shifted to 'Ek en my manskappe/soldate'. This shift resonated with the context from 1948 to the intensification of the struggle for liberation. The African Languages consistently interpret and translate as 'people'. The only creativity they show is to interchange between the 'nation' or the 'tribe'. None of the African Languages interpret and translate as 'soldiers'. The apparent contradictory linguistic interpretation and translation of וְעִ is that there is a tendency to be correct in terms of the Hebrew, also the creativity of the interpreters in terms of their contemporary context and the suspicion of the support for the status quo or the resistance thereto.

The last three verses deal with the fight between the Gileadites under Jephthah and the men of Ephraim and it is about the narrative ethnocentricization of the fight in the first place rather than laying bare the reality that the fight was for the control of the toll at the Jordan fords. The reason given by the men of Ephraim in verse 1 is evidence for our contention. Almost without exception the interpretations and translations miss this crucial

20 Charles van Engen in Bivin, Mother-Tongue Translations and Contextualization.

21 Ezra Chitando and Masiiwa R Gunda, "HIV and AIDS, Stigma and Liberation in the Old Testament." Exchange 36 2007:184-197. 
aspect and rather further ethnocentricise in their respective languages within which the translation enterprise takes place.

3

All the African Languages translations without exception render the expression literally. The Afrikaans translation on the contrary renders the expression as 'under my power'.

Morena a ba gafela diatleng tsa ka (Judges 12:3 Sepedi)

Morena a neelana ka bona matsohong a ka (Judges 12:3 Sesotho)

MORENA a ba neela mo diatleng tsa me (Judges 12:3 Setswana)

Simakade wawanikela esandleni sami, ngawancoba (Judges 12:3 siSwati)

Yehova a mbo vha kumedzela zwandani zwanga (Judges 12:3 Tshivenda)

Yehiva a wa nyiketa a mavokweni ya mina (Judges 12:3 Xitsonga)

Die Here het hulle in my mag opgegee (Rigters 12:3 Afrikaans)

the LORD gave them into my hand (Judges 12:3 English)

uYehova wabanikela esandleni sam (Judges 12:3 isiXhosa)

uJehova wabanikela esandleni sami; (Judges 12:3 isiZulu)

The narrative on the victory of the Gileadites under Jephthah mutes and omits an important incident, namely, the vow he made with Yahweh and who paid the price for Jephthah's safe homecoming. Almost all the interpretations and translations without exception collude with the narrative by heaping praises for Jephthah's courage and selflessness at the expense of the daughter who was 'offered as a sacrifice'. The translations also collude with the narrative in placing Yahweh exclusively on the side of Jephthah not only in the case of his fight with the sons of Ammon and by implication his daughter but also against the men of Ephraim as we will see in the last three verses.

The response of Jephthah to the men of Ephraim is a narration of the events narrated in Judges 11. The question is whose voice of protest and resistance is being muted, silenced and ultimately omitted in the grand chorus of the human experience yearning for liberation? What all the interpretations and translations are doing is actually to fail the daughter who was sacrificed and continue to be sacrificed by muting and omitting their experiences and stories from the grand narrative of the human story including history and her story.

The pertinent question being raised here is whether we may continue to invoke YHWH to sanction our violence towards the Other. One may see that in the retelling of the events that are narrated in Judges 11 the vow and the sacrifice are being conveniently omitted. Maybe this is an indication of the narrator zapping Jephthah based on the criticism that may have followed following his ambush and guerilla appropriation of YHWH to sanction violence against his daughter (Judges 11) and now about to do the same against the men of Ephraim. The fact that the vow and the sacrifice of the daughter have been omitted in the present verse does not cancel their existence in the first place. The fact of the matter is that they remain present in spite of their narrative absence. Our task as readers is to expose the omission and reconstruct the voice of the daughter that is yearning for justice. The least we may do is to expose the lie that it was Jephthah's life that was at risk when in actual fact it is the daughter's life that was not only risked but that she was sacrificed at a virginal age.

The last three verses deal with the fight between the Gileadites under Jephthah and the men of Ephraim and it is about the narrative ethnocentricization of the fight in the first place rather than laying bare the reality that the fight was for the control of the proceeds of 
the toll at the Jordan fords. The reason given by the men of Ephraim in verse 1 is evidence for our contention. Almost without exception the interpretations and translations miss this crucial aspect and rather further ethnocentricise the events in their respective languages within which the translation enterprise takes place.

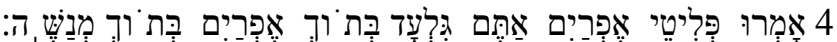

The African Languages translations are divided between fugitives and renegades in their rendering of פְִִּּיטי: 'batshabi' (Judges 12:4 Sepedi), 'babalehi' (Judges 12:4 Sesotho), 'vhashavhi' (Judges 12:4 Tshivenda), 'ningabasabileyo' (Judges 12:4 isiXhosa), 'ningababalekileyo' (Judges 12:4 isiZulu); 'bafaladi' (Judges 12:4 Setswana), 'ningemambuka' (Judges 12:4 siSwati), 'vahlongoriwa' (Judges 12:4 Xitsonga). The Sesotho translation introduces a tribe 'morabe' (Judges 12:4 presumably following the Afrikaans which introduces 'stam' (Rigters 12:4 Afrikaans). The Afrikaans translation evolved from 'vlugtelinge' (Rigters 12:4 Afrikaans) 'weglopers' (Rigters 12:4 Afrikaans), 'weggedros' (Rigters 12:4 Afrikaans). The English translation renders it 'fugitives' (Judges 12:4 English).

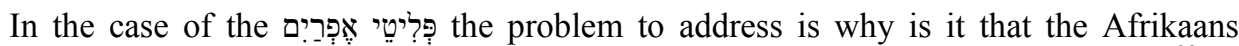
interpretations and translations appear to highlight the importance of the stigmatizing ${ }^{22}$ of the Gileadites by the men of Ephraim whereas the African Languages seems to be eluded by it.

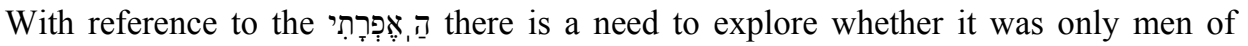
Ephraim who were fording the Jordan or there were other people as well who may have been victimized as a result of failing the pronunciation test. ${ }^{23}$ In the case of xenophobia and Afrophobia in South Africa the victims included the South Africans as well and not just the nationals of other countries. ${ }^{24}$

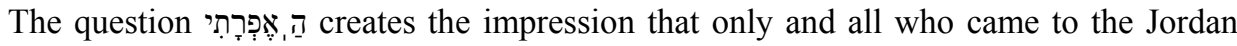
fords were Ephraimites when in actual fact it could have been those who could simply not pronounce because they were not Ephraimites and also Ephraimites themselves who could pronounce the same as the Gileadites.

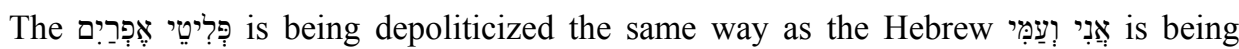
demilitarized even though the context demands otherwise. The African Languages smooth

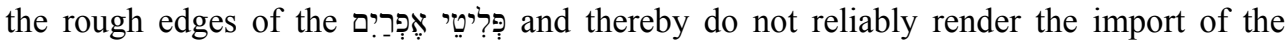
message being conveyed. Instead what the African Languages do is to resort to what the practitioners have been taught and learnt best, namely, ethnocentricize the conflict and struggle for hegemony in general and in particular disregard the conflict for control of the trade route through the Jordan fords. It is important at this point to stress that even the opposition that accuses the one in control of the toll gate they are equally envious of the reins of power. The narrative uses the label of dissenters to portray the labeling of the Gileadites in general and Jephthah in particular by the Ephraimites but this is not being picked up in the interpretations and translations in the African Languages as it is in the Afrikaans official and independent versions. This is so when the social context within which the interpretation and translation enterprise is being peddled and that there is so much labels to choose from.

22 Chitando and Gunda, HIV and AIDS, Stigma, 186-189.

23 Willesen, Folker. "The אפרתי of the shibboleth incident." Vetus Testamentum, 8:1 January 1958:97-98.

24 Shireen, Kupe and Worby: Violence, Xenophobia and Reinvention of Difference in South Africa. 
There appears to have been several reasons behind the fight. In the first place, the confrontation of Jephthah by the men of Ephraim and secondly, the labeling of the Gileadites as renegades, dissenters. There is surely some ideological interests being served by the translations that conveniently overlook the import of 'renegade' but instead focus on 'tribe'. As part of the search for what the ideological interest is we need to ask the question whether this is part of the internal resistance or internal collaboration with the status quo as it has been suggested and suspected. In this regard one only wonders what in contemporary situation and amongst the African Languages could have occasioned such tribal interpretation and translation as is borne in the Sesotho Translation except of course conformity to the grand apartheid policy of division of black people in terms of the languages they speak. The point we wish to make is that there is no way that we could go on with ethnic and tribal Sesotho translation and that there is no need in the democratic dispensation for us to use the Bible to sanction tribalism and ethnocentricism. Surely the epistemology ${ }^{25}$ and the process of knowledge production evidenced by the interpretation and translation and amongst Black People may not be along tribal and ethnocentric lines and be allowed to be linguistically contradictory as it is portrayed in the interpretation and translation in the African Languages.

The African Languages are divided between 'a survivor': 'mophonyogi' (Judges 12:5 Sepedi), 'ba phonyohileng' (Judges 12:5 Sesotho), 'lophunyilile' (Judges 12:5 siSwati), 'ponyoka' (Judges 12:5 Tshivenda); and a 'fugitive': 'motshabi' (Judges 12:5 Setswana), 'abasabileyo' (Judges 12:5 isiXhosa), 'ababalekileyo' (Judges 12:5 isiZulu). Also, what is of importance to note is that the translations render either in the singular or in the plural, presumably following the Afrikaans which renders it as such 'vlugtelinge' (Rigters 12:5 Afrikaans).

The previous verse and the current one both use the יפְִּ to refer to 'renegades' and 'escapees', respectively. When the men of Ephraim label the Gileadites as 'renegades' in vs. 4, they are now portrayed as 'survivors' who are now running away back home. We need to remember though, that it was not only the men of Ephraim who passed through the Jordan fords. The actual reason for the fight in the first place is now being revealed, namely, control of the proceeds of the toll at the Jordan fords. It may have had something to do with the jealousy over the spoils in the fight with the sons of Ammon, but here at the fords of the Jordan it is mainly about the proceeds of the toll.

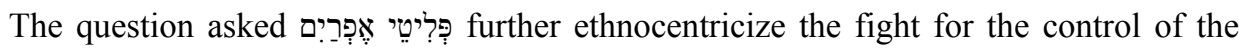
trade route. The impression being created is that it was only the Ephraimites who was passing at the Jordan fords when in actual fact deconstruction of the narrative points to the contrary.

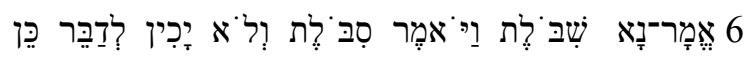

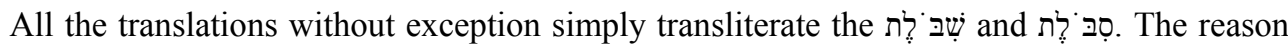

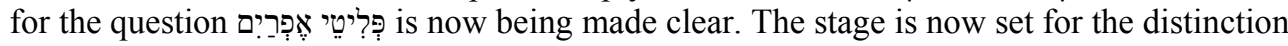

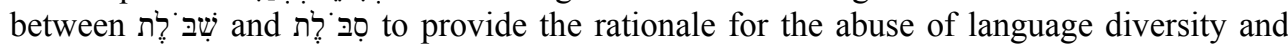
dialect pronunciation as the basis for discrimination and violent destruction. What took place at the fords of the Jordan between the Gileadites under the leadership of Jephthah and

25 Botha, "If everything is contextualisation, nothing is contextualization," 189-190. 
the Ephraimites has been compared to the situation of xenophobia and Afrophobia that took place in South Africa in 2008:

Now, in the view of many South Africans, it seems that the rainbow has been displaced by the onion: a way of imagining degrees of national belonging. Layered around an authentic core. In this view, the fragile outer skin is made up of black African immigrants: Somalians, Congolese, Zimbabweans. Beneath that fragile exterior - so easily exfoliated and discarded - Lie the Tsonga, Shangaan, Venda and Pedi, people with a firmer claim to inclusion, but on the periphery of the political heartland and therefore of dubious loyalty to the national project. In the vortex of the attacks, those testing for authenticity and looking for deserving victims used the Old Testament technique of the shibboleth, demanding of those whose true nationality remained in doubt to correctly render the IsiZulu word for elbow - indololwane - or face the brutal consequences. $^{26}$

Ambush and guerilla tactic continues with the use of the pronunciation test. A third reason is provided for the end of the mayhem, namely, the failure of the pronunciation test. Unsuspecting readers may be misled to think that it is about passing the pronunciation test and succumb to ethnocentric interpretation and translation, this needs to be avoided at all cost because the issue is not language or pronunciation but control of economic resources as in the same way as it was with the military power against the sons of Ammon. It is amazing to see how the different 11 African languages have constructed the incident for their readers given the erstwhile racial classification and linguistic divide and rule official policy. As for the African Languages what needs to be surfaced is the common black experience and not the contradictory pronunciations.

The ethnocentricization reaches climax with the scholarly focus only on the oִּ a שִ שִבּ לֶת where they blow out of proportion discrimination based on the ability and inability to pronounce as if the narrative is just about the Ephraimites. The difference between the and 0 is being made to provide an explanation for the fight between the Gileadites and the men of Ephraim. The Gileadites fought with the sons of Ammon not because of inability at pronunciation.

The six verses are joined by the fact that the three groups are fighting for control of the trade route. The connection between the sons of Ammon, the Gileadites and the men of Ephraim has been made albeit only as a means to condemn Jephthah. The Gileadites fought with the sons of Ammon not because of inability at pronunciation but presumably because of etnocentricization. This connection is however missed in the interpretations and translations. Interpretations and translations are social constructs and as such are subject to deconstruction in order to expose and undermine the interests they serve and the ideological biases of the narrators. Also, the muted and omitted voices in these narratives need to be amplified by means of reconstruction.

The six verses are joined by the fact that the three groups are fighting for military power and economic control of the trade route at the Jordan fords. The connection between the sons of Ammon, the Gileadites and the men of Ephraim has been made albeit only as a means to focus on the power exercised by Jephthah. The Gileadites fought with the sons of Ammon not because of inability at pronunciation. This connection is however missed in the interpretations and translations that focus only on the pronunciation test in the fight between the men of Gilead and the men of Ephrim.

26 Shireen, Kupe and Worby, Violence, Xenophobia and Reinvention of Difference in South Africa, 16. 
Ambush and guerilla tactic continues with the use of the pronunciation test. A third reason is provided for the end of the mayhem, namely, the failure of the pronunciation test. Unsuspecting readers may be misled to think that it is about passing the pronunciation test and succumb to ethnocentric interpretation and translation, this needs to be avoided at all cost because the issue is not language or pronunciation but control of economic resources as in the same way as it was with the military power against the sons of Ammon. Given the fact that the translation is not in the hands of the people who speak the African Languages it is not surprising to see how the incident at the Jordan fords has been constructed in the 11 African languages for their readers given the erstwhile racial classification and linguistic divide and rule official policy. As for the African Languages, what needs to be surfaced, is the common black experience and not the contradictory pronunciations.

The six verses are joined together by the fact that the three groups are fighting for military power and economic control of the trade route at the Jordan fords. The connection between the sons of Ammon, the Gileadites and the men of Ephraim has been made albeit only as a means to focus on the power exercised by Jephthah. The Gileadites fought with the sons of Ammon not because of inability at pronunciation. This connection is however missed in the interpretations and translations that focus only on the pronunciation test in the fight between the men of Gilead and the men of Ephraim.

\section{Conclusion}

The Afrikaans translations rightfully focus on the receiving community when they translate Judges 12:1-6 to resonate with the historical experience of the Afrikaner people. When they do this their actions are being justified and legitimized that they are the chosen people of God who can do as they please. When they were applying the שִׁבּ לְת thechnique etc. nobody lifted a voice. The African Languages' translations on the contrary do not make those associations. Is it because they do not want the speakers of these languages to claim the status of being the receiving community of the biblical text and also share in the status of being chosen? The xenophobia and Afrophobia of 2008, on the contrary, apply the villains in the story (in this case Jephthah and the Gileadites) without exception as Black South Africans.

Xenophobia and Afrophobia have deep roots and for it to be uprooted a lot needs to be done - including that fire is not an option to resolve apparent conflict between the equal bearers of the image of God irrespective of their race/ethnicity, social class, gender and nationality. The construction of 'I and my people' in the African Languages translations needs to be inclusive and not exclusive in conformity to the dictates of apartheid ethnocentricism and now exclusion on the basis of nationality. We cannot continue to claim God on our side alone in order to legitimize violence against fellow South Africans and the Black African Other. We are also called upon to refrain from the xenophobic and genealogical construction of the Other on the basis of their genealogy. Last but not least, in order to uproot xenophobia and Afrophobia we need to focus on eradicating its seeds and all the stages of its progression and nib it in the bud rather than wait to address its climax as in the case of the difference between the pronunciation of and סִּב לֶת exploitation of diversity as the basis of stigma, discrimination and violence together with the abuse of the biblical text for their legitimation needs to be addressed at their earliest detection.

Towards this end the proponents and practitioners of South African Black Theology needs to get her act in order by having her own interpretation and translation of the Bible 
informed by the cosmology and epistemology ${ }^{27}$ emerging from the Black experience. The interpretations and translations of the Bible into African Languages appear to be an attempt to serve the goal of smuggling in the divide and rule strategy and by sanctioning it by religion. ${ }^{28}$ The process and product of such activity will enhance the integral connection and inalienability between Black Theology and Black People. It will also dispel the charge of questioning the sacred sources but the narrative and interpretations and translations that underscore and sanction any oppressive status quo. Furthermore it will show that Black Theology is not just for a few individuals but for the church and community of which it is an integral part. Contest ideological formations that use the sacred sources and their interpretations and translations to undergird the status quo. What readers need, therefore, is an interpretation and translation in the form of a text to deal with the Black experience in the privacy of their studies, prisons, homes, etc. The text will go a long way to assist our brothers and sisters who are at the receiving end of violence against them to make informed connections between their struggles and the struggles they read about in the whole narrative of Judges 12:1-6 and not just focus on the shibboleth technique. Also, the text will provide insight on the choices to be made between reference to a specific place or direction and the demilitarisation constructs. In particular, enhance the readers' ability to hearken to the sound of narrative silences, muted voices and the inclusion of the omitted voice. We will be able to celebrate diversity of life experience including languages and the people who speak them as a gift rather than use it as the basis for advocating of violence against one another, especially against the Black African Other.

\section{BIBLIOGRAPHY}

Bivin, William E 2010. "Mother-Tongue Translations and Contextualization in Latin America." International Bulletin of Missionary Research 34/2 April, pp. 72-76.

Botha, NA 2010. "If everything is contextualisation, nothing is contextualization: Historical, methodological and epistemological perspectives." Missionalia 38/2 August, pp. 181-196.

Chitando, Ezra and Gunda, Masiiwa R 2007. "HIV and AIDS, stigma and liberation in the Old Testament." Exchange 36 no 2, pp. 184-197.

Gathogo, JM \& Phiri, IA 2009. "Xenophobia/Afrophobia in Post-Apartheid (South) Africa: Strategies for Combat" Theologia Viatorum 33/2, pp. 216-241.

Lübbe, John 2009. “A New Bible translation: “The Syntactic Translation"?" Old Testament Essays 22/3, pp. 605-617.

Maimela, Simon S 1981a. "Man in "White" Theology." Missionalia 9/2 August, pp. 64-78.

Maimela, Simon S 1981b. "Man in "White" Theology." Journal of Theology for Southern Africa, pp. 27-42.

Masenya, Madipoane 2001. "What differences do African contexts make for English translations?" Old Testament Essays 14/2, pp. 281-296.

Nadar, Sarojini 2009. "““The Bible Says!” Feminism, Hermeneutics and Neo-Pentecostal Challenges." Journal of Theology for Southern Africa 134, pp. 131-146.

27 Botha, "If everything is contextualisation, nothing is contextualization," 189-190.

28 'Morabe' (Judges 12:4 Sesotho), 'stam' (Rigters 12:4 Afrikaans) constructs that resonate with the apartheid policy and discourse. 
Nel, Reginald W \& Makofane, Karabo M Makofane, 2009. "Exploring the Notion of the 'African Other', from the Perspective of 'Oikos', towards Building Inclusivity: Reflections on the Response of URCSA in the Wake of the Recent Violent Attacks against Black African Nationals" Theologia Viatorum 33/2, pp. 374-399.

Pityana, Barney N and Villa-Vicencio, (eds.) 1995. Being the Church in South Today Papers delivered at the consultation on South Africa in Regional and Global Context: Being the Church Today. Vanderbijlpark March 19-23. Johannesburg: South African Council of Churches.

Shireen, Hassim, Tawana Kupe, and Eric Worby, (eds.) 2008. Go Home or die Here: Violence, Xenophobia and Reinvention of Difference in South Africa. Johannesburg, South Africa: Wits University Press.

Stiebert, Johanna 2001. "Does the Hebrew Bible have anything to tell us about HIV/AIDS?” Missionalia 29/2 August, pp. 174-185.

Willesen, Folker 1958. "The אפרתי of the shibboleth incident." Vetus Testamentum, 8:1 January, pp.97-98. 